\title{
KAJIAN KARAKTERISTIK DAN EVALUASI PRODUKSI TERNAK KAMBING BERDASARKAN INDIKATOR KETERSEDIAAN PAKAN DI KABUPATEN MUNA BARAT
}

\author{
Irwansyah $^{1}$, Takdir Saili ${ }^{2}$, La Ode Nafiu ${ }^{2}$ \\ ${ }^{1)}$ Alumnus Prodi Peternakan PPs UHO \\ ${ }^{2)}$ Staf Pengajar Fakultas Peternakan UHO \\ email : takdir69@yahoo.com
}

\begin{abstract}
Abstrak
Kabupaten Muna Barat merupakan daerah yang cukup potensial untuk pengembangan peternakan kambing. Namun demikian, tingkat produktivitas kambing pada masing-masing di daerah Kabupaten Muna Barat dan dukungan sumber daya pakan belum diketahui dengan pasti, sehingga dibutuhkan informasi detail tentang potensi ketersediaan pakan untuk memenuhi kebutuhan produksi sebelum mengembangkan peternakan kambing. Penelitian ini bertujuan untuk menghitung daya tampung ternak kambing berdasarkan ketersediaan pakan di 18 desa dari 6 wilayah kecamatan yaitu Kecamatan Kusambi, Napano Kusambi, Lawa, Tiworo Tengah, Tiworo Selatan dan Kecamatan Tiwori Kepulauan berdasarkan kriteria kepemilikan populasi. Pengambilan data primer terdiri dari 101 responden dengan jumlah ternak sebanyak 408 ekor. Ketersediaan pakan dihitung berdasarkan produksi bahan pakan dikalikan dengan luas panen dan dinyatakan dalam bahan kering (BK) dan bahan organik (BO). Produksi sampel pakan hijauan diperoleh dari pengambilan cuplikan/pengubinan rumput dan hasil ikutan pertanian. Produksi hijauan legum dihitung berdasarkan produksi perpohon dikalikan luas panen hijauan. Hasil penelitian menunjukkan bahwa dengan produksi bahan pakan, masih dapat mengembangkan ternak kambing sebanyak 359,52 UT/ha (2.247 ekor) atau 227,5 UT sapi perhektar.
\end{abstract}

Kata kunci: Produksi Kambing, Pakan, Kapasitas Tampung

\begin{abstract}
West Muna regency is quite potential for development of livestock goats. However, the productivity level of goat in every region of West Muna regency and support of animal feed resources have been unknown for sure, therefore detailed information about the potential of animal feed resources is needed to be able fulfill production needs before developing goat farms. This study aimed to calculate the carrying capacity of goat farm based on the availability of animal feed in 18 villages within 6 sub-regencies including Kusambi, Napano Kusambi, Lawa, Central Tiworo, South Tiworo, and Tiworo Islands based on a criteria of population ownership. Primary data were collected from 101 respondents with a total of 408 animal units. The availability of animal feed was calculated by multiplying production of animal feed with harvested area and was expressed in dried materials (BK) and organic materials (BO). Samples of the production of green animal feed was obtained by taking grass from protected square meter and agricultural by products. Production of green legumes was calculated based on the production of each tree multiplies with harvested green area. Result of the study showed that with the current production of animal feed it is still possible to develop goat farm up to 359.52 UT/ha (2.247 animal units) or 227.5 UT cow per hectare.
\end{abstract}

Keywords: production of goats, animal feed, carrying capacity 


\section{PENDAHULUAN}

Peluang bagi perkembangan produksi kambing secara nasional pada dasarnya cukup tinggi, karena terdapat berbagai indikator baik teknis, biologis, sosial maupun ekonomi yang kondusif bagi usaha produksi. Kambing sering menjadi pilihan prioritas dalam berbagai acara keagamaan dan sosial, sehingga tidak selamanya dapat digantikan oleh jenis ternak lain. Potensi pengembangan ternak kambing ini adalah peluang yang sangat baik untuk mengembangkan usaha peternakan kambing.

Sumber daya genetik ternak pada saat ini menghadapi tantangan ganda. Pada satu sisi, permintaan produk peternakan meningkat di negara berkembang, seperti diestimasikan oleh Food Agriculture Organization (FAO), bahwa permintaan susu dan daging asal ternak akan meningkat dua kali lipat. Di sisi lain, sumberdaya genetik ternak semakin terancam keberadaannya di seluruh dunia. Sejak 15 tahun lampau hingga kini, 300 dari 6000 breed yang diidentifikasi oleh FAO mengalami kepunahan (Ruane et al., 2006).

$$
\text { Ditinjau dari aspek }
$$

pengembangannya ternak kambing sangat potensial bila diusahakan secara komersial, hal ini disebabkan ternak kambing memiliki beberapa kelebihan dan potensi ekonomi antara lain tubuhnya relatif kecil, cepat mencapai dewasa kelamin, pemeliharaannya relatif mudah, tidak membutuhkan lahan yang luas, investasi modal usaha relatif kecil, mudah dipasarkan sehingga modal usaha cepat berputar (Atmojo, 2007).

Masalah yang sering dihadapi para peternak adalah yang berkaitan dengan ketersediaan sumber hijauan, khususnya selama musim kemarau. Menurut Mulyono dan Sarwono (2008), pada dasarnya kambing tidak selektif dalam memilih pakan. Segala macam daun-daunan dan rumput disukai, tetapi hijauan dari daun-daunan lebih disukai dibandingkan rumput. Hijauan yang baik untuk pakan adalah hijauan yang belum terlalu tua dan belum menghasilkan bunga karena hijauan yang masih muda memiliki kandungan PK (protein kasar) yang lebih tinggi.

Kabupaten Muna Barat merupakan salah satu Kabupaten di Provinsi Sulawesi Tenggara yang cukup potensial untuk pengembangan peternakan khususnya peternakan kambing. Namun demikian, tingkat produktivitas kambing di daerah Kabupaten Muna Barat. dan dukungan sumber daya alam melalui penyediaan pakan belum diketahui dengan pasti. Sehubungan dengan hal tersebut, perlu dilakukan suatu kajian tentang karakteristik populasi dan evaluasi produksi ternak kambing berdasarkan indikator ketersediaan pakan.

\section{MATERI DAN METODE}

Penelitian ini telah dilaksanakan pada bulan Februari sampai dengan Mei 2016 pada 6 (enam) kecamatan dari 11 kecamatan yang ada di Kabupaten Muna Barat Sulawesi Tenggara yakni Kecamatan Kusambi, Napano Kusambi, Lawa, Tiworo Tengah, Tiworo Selatan dan Tiworo Kepulauan. Pemilihan lokasi ini ditentukan dengan menggunakan metode stratified random sampling yaitu suatu metode penentuan lokasi penelitian yang didasarkan dengan pertimbangan-pertimbangan tertentu (Rianse dan Abdi, 2009).

Populasi penelitian ini adalah semua peternak kambing pada 6 wilayah yang telah diklasifikasi. Setiap kecamatan diambil sampel desa dengan menggunakan metode stratified random sampling berdasarkan kriteria kepemilikan populasi kambing kategori tinggi, kepemilikan populasi sedang dan kepemilikan populasi rendah. 
Responden penelitian ini ditetapkan semua peternak dari setiap desa yang ditetapkan sebagai sampel yang berjumlah 101 rumah tangga peternak dengan menggunakan metode sensus. Pengambilan sampel pakan ternak kambing dilakukan dengan mengambil sampel secara langsung dilokasi/lahan pemeliharaan milik peternak kemudian dilakukan analisis proksimat untuk mengetahui kadar bahan kering (BK) dan bahan organik (BO) pakan. Perhitungan produksi pakan hijauan legum dilakukan dengan cara perhitungan sampel produksi/pohon dikali jumlah pohon/luas panen. Sedangkan produksi hijauan rumput lapangan dan hasil ikutan pertanian dilakukan dengan pengambilan sampel cuplikan/ubinan yang menggunakan kuadran $\left(\mathrm{m}^{2}\right)$.

Tabel 1. Jenis Bahan Pakan Ternak Kambing di Lokasi Penelitian

\begin{tabular}{|c|l|c|c|}
\hline \multirow{2}{*}{ No } & \multirow{2}{*}{ Bahan pakan } & \multicolumn{2}{|c|}{ Nutrisi bahan pakan (\%) } \\
\cline { 3 - 4 } & & BK & BO \\
\hline 1 & Daun gamal & 40,06 & 90,48 \\
\hline 2 & Daun lamtoro & 31,85 & 91,72 \\
\hline 3 & Rumput lapangan & 29,05 & 92,51 \\
\hline 4 & Daun ubi kayu & 14,50 & 92,22 \\
\hline 5 & Daun ubi jalar & 11,24 & 85,85 \\
\hline
\end{tabular}

Sumber: Hasil Analisis Proksimat Laboratorium Jurusan Peternakan

\section{Analisis Data}

\section{Analisis Data Kualitatif}

Analisis kualitatif merupakan penganalisisan data yang tidak dapat dinominalkan dengan menggunakan angka-angka, melainkan disajikan berupa keterangan, penjelasan dan pembahasan teori secara deskriptif. Data penelitian ini yang menggunakan analisis data kualitatif adalah sebagai berikut:

1. Analisis karakteristik ternak kambing meliputi jumlah dan struktur populasi ternak kambing yang dimiliki oleh peternak.

2. Produksi ternak kambing dengan indikator ketersediaan pakan dihitung dengan melakukan penimbangan ternak kambing milik peternak berdasarkan umur ternak yaitu umur 0-6 bulan, >6-
13 bulan, dan umur >13 (Syamyono, 2014).

3. Menghitung kapasitas tampung ternak kambing berdasarkan ketersediaan bahan kering (BK) dan bahan organik (BO) dari pakan dilakukan dengan analisis proksimat bahan pakan di Laboratorium Nutrisi dan Makanan Ternak, Fakultas Peternakan Universitas Halu Oleo Kendari. Data yang diperoleh berupa jumlah atau ketersediaan sumber pakan kemudian dikonversikan tehadap kapasitas daya tampung satuan ternak (ST). 
Tabel 2. Struktur Populasi Ternak dan Standar Satuan Ternak Menurut Umur dan Jenis Ternak.

\begin{tabular}{ccc}
\hline Struktur umur ternak & $\begin{array}{c}\text { Standar satuan ternak } \\
\text { kambing (ST) }\end{array}$ & $\begin{array}{c}\text { Standar satuan ternak } \\
\text { sapi (ST) }\end{array}$ \\
\hline Anak & 0,04 & 0,25 \\
\hline Muda & 0,08 & 0,60 \\
\hline Dewasa & 0,16 & 1,00 \\
\hline
\end{tabular}

Hasil perhitungan satuan unit ternak (Soekoharto, 1990).

\section{Analisis Data Kuantitatif}

Uji data kuantitatif yang digunakan dalam penelitian ini sebagai berikut:

\section{Uji F (Uji Simultan)}

Uji F (Uji Simultan) digunakan untuk mengetahui hubungan antara variabel independent dan variabel dependent, apakah variabel bebas benar-benar berpengaruh secara simultan (bersama-sama) terhadap variabel dependen $\mathrm{Y}$.

Langkah-langkah pengujiannya adalah sebagai berikut (Ghozali, 2005)

1. Menentukan formulasi hipotesis

- $\mathrm{H} 0=0$, artinya variabel X1, $\mathrm{X} 2$, dan $\mathrm{Xn}$ tidak mempunyai pengaruh yang signifikan secara simultan terhadap variabel Y.

- H0 : $\neq 0$, artinya variabel $\mathrm{X} 1, \mathrm{X} 2$, dan Xn mempunyai pengaruh yang signifikan secara simultan terhadap variabel Y.

2. Menentukan derajat kepercayaan $95 \%(\alpha=0,05)$

3. Menentukan signifikansi

- Nilai signifikasi $(P$ Value $)<$ 0,05 maka $\mathrm{H} 0$ ditolak dan Ha diterima.

- Nilai signifikasi $(P$ Value $)>$ 0,05 maka $\mathrm{H} 0$ diterima dan Ha ditolak.

4. Membuat kesimpulan
- Bila $(P$ Value $)<0,05$ maka $\mathrm{H} 0$ ditolak dan Ha diterima. Artinya variabel independent secara simultan (bersama-sama)

mempengaruhi variabel dependent.

- Bila $(P$ Value $)>0,05$ maka H0 diterima dan Ha ditolak. Artinya variabel independent secara simultan (bersama-sama) tidak mempengaruhi variabel dependent.

\section{Uji t (parsial)}

Uji t (parsial) digunakan untuk menguji berarti atau tidaknya hubungan variabel-variabel independent, apakah variabel pengalaman beternak (X1), jumlah ternak awal (X2), kepemilikan induk (X3) dan total BK pakan (X4) benar-benar berpengaruh secara parsial (sendiri-sendiri) terhadap variabel dependen Y (jumlah ternak lahir).

\section{Analisis Regresi Linear Berganda}

Analisis regresi linier berganda digunakan untuk mengetahui seberapa besar pengaruh hubungan variabel pengalaman beternak (X1), jumlah ternak awal (X2), kepemilikan induk (X3) dan total BK pakan (X4) terhadap variabel dependen jumlah ternak lahir (Y). 
Bentuk persamaan regresi yang digunakan adalah:

$$
\begin{array}{r}
\mathrm{Y}=\mathrm{a}+\mathrm{b}_{1} \mathrm{X}_{1}+\mathrm{b}_{2} \mathrm{X}_{2}+\mathrm{b}_{3} \mathrm{X}_{3}+\mathrm{b}_{n} \mathrm{X}_{\mathrm{n}}+\mathrm{e} \\
\text { Keterangan : } \mathrm{Y}=\text { Kepuasan pasien } \\
\mathrm{b}_{1}=\text { Koefisien regresi } \\
\text { dari variabel } \mathrm{X}_{1} \text { (pengalaman beternak) } \\
\mathrm{X}_{1}=\text { Pengalaman bternak } \\
\mathrm{b}_{2}=\text { Koefisien regresi } \\
\text { dari variabel } \mathrm{X}_{2} \text { (Jumlah ternak awal) } \\
\mathrm{X}_{2}=\text { Jumlahternak awal } \\
\mathrm{b}_{3}=\text { Koefisien regresi } \\
\text { dari variabel } \mathrm{X}_{3}(\text { Kepemilikan induk) } \\
\mathrm{X}_{3}=\text { kepemilikan induk } \\
\mathrm{b}_{4}=\text { Koefisien regresi } \\
\text { dari variabel } \mathrm{X}_{4} \text { (Total BK pakan) } \\
\mathrm{X}_{4}=\text { Total BK pakan } \\
\mathrm{e}=\text { Standar error }
\end{array}
$$

(Gujarat, 2003)

\section{HASIL DAN PEMBAHASAN}

\section{Gambaran Umum Wilayah}

Kabupaten Muna Barat terdiri dari 11 kecamatan, antara lain yaitu Kecamatan Kusambi, Napano Kusambi, Barangka, Sawerigadi, Lawa, Wadaga, Tiworo Kepulauan, Tiworo Tengah, Tiworo Utara, Maginti, dan Tiworo Selatan. Ditinjau dari 11 kecamatan tersebut keseluruhan merupakan kecamatan swasembada. Berdasarkan penggunaannya, sebagian besar lahannya merupakan areal pertanian, sebagian besar merupakan lahan kering tadah hujan yang pemanfaatan potensinya sangat tergantung pada curah hujan yang ada. Sebagian besar penduduknya bermata pencaharian sebagai petani. Produksi hasil pertanian di Kabupaten Muna Barat berupa padi dan jagung (Pemerintah Kabupaten Muna Barat, 2016).

\section{Keadaan Peternakan Kambing}

Populasi ternak kambing yang ada di Kabupaten Muna Barat berjumlah 4.216 ekor yang tersebar pada 11 wilayah kecamatan dan merupakan populasi terbanyak kedua setelah ternak sapi. Jumlah populasi ternak kambing yang ada di 6 wilayah kecamatan sebagai lokasi penelitian yaitu 408 ekor. Jenis bahan pakan yang paling banyak diberikan peternak kepada ternaknya selama 10 hari pada penelitian pendahuluan yaitu daun gamal sebagai pakan utama, daun lamtoro serta hasil ikuan pertanian seperti daun ubi kayu dan daun ubi jalar. Tingginya produksi limbah tanaman pertanian dipengaruhi oleh luas areal panen tanaman pangan yang besar dan jumlah panenan yang dilakukan.

\section{Jumlah dan Struktur Populasi Tenak Kambing}

Kepemilikan ternak kambing di lokasi penelitian terdiri dari berbagai kategori umur yaitu anak, muda dan dewasa. Sesuai dengan pendapat (Syamyono, 2014) menyatakan bahwa kelompok anak umur 3-6 bulan, muda $>6-13$ bulan dan kategori dewasa berumur $>13$ bulan. 
Tabel 3. Distribusi Peternak berdasarkan Jumlah dan Struktur Populasi Ternak Kambing

\begin{tabular}{|c|c|c|c|c|c|c|c|}
\hline \multirow{2}{*}{ Kecamatan } & \multicolumn{5}{|c|}{ Struktur populasi ternak kambing (ekor) } & \multirow{2}{*}{$\begin{array}{c}\text { Jumlah } \\
\text { (ekor) }\end{array}$} \\
\cline { 2 - 8 } & \multicolumn{2}{|c|}{ Anak } & \multicolumn{2}{c|}{ Muda } & \multicolumn{2}{c|}{ Dewasa } \\
\cline { 2 - 8 } & Jantan & Betina & Jantan & Betina & Jantan & Betina & \\
\hline 1 & 7 & 21 & 5 & 18 & 19 & 29 & 99 \\
\hline 2 & 5 & 20 & 5 & 9 & 15 & 24 & 78 \\
\hline 3 & 7 & 11 & 2 & 8 & 13 & 22 & 63 \\
\hline 4 & 10 & 14 & 3 & 9 & 10 & 21 & 67 \\
\hline 5 & 11 & 14 & 1 & 7 & 8 & 21 & 62 \\
\hline 6 & 4 & 8 & 2 & 1 & 8 & 16 & 39 \\
\hline Total (ekor) & 44 & 88 & 18 & 52 & 73 & 133 & 408 \\
\hline Rata-rata (ekor) & 7,33 & 14,67 & 3 & 8,67 & 12,17 & 22,17 & 68 \\
\hline Satuan Ternak/ST & \multicolumn{3}{|c|}{5,28} & \multicolumn{7}{c|}{5,60} & 32,96 & 43,84 \\
\hline
\end{tabular}

Sumber: data primer penelitian

Keterangan: Kategori ternak anak $=$ umur 0-6 bulan, Kategori ternak muda $=$ umur $>6-13$

Kategori ternak dewasa $=$ umur $>13$

Berdasarkan data pada Tabel 3 bahwa populasi ternak kambing di lokasi penelitian terdiri dari 132 ekor kategori anak, 70 ekor kategori muda dan 206 ekor ternak kategori dewasa. Dari 408 ekor ternak kambing di lokasi penelitian, setelah di konversikan kedalam satuan ternak yaitu 43,84 ST atau setara dengan 274 ekor ternak dewasa. Rata-rata kepemilikan ternak kambing/kecamatan kategori anak yaitu 22 ekor anak, 12 ekor kategori ternak muda dan 34 ekor ternak dewasa. Total jumlah ternak kategori muda sebanyak
70 ekor dari seluruh kecamatan, memiliki persentase terendah dibandingkan dengan ternak anak dan jumlah ternak dewasa hal ini disebabkan tingginya tingkat penjualan ternak muda oleh peternak. Hal ini sesuai dengan pernyataan bahwa sistem penjualan ternak masih didasarkan atas kebutuhan uang tunai, sehingga pengelolaan ternak yang dilakukan tidak menjamin kontinuitas pendapatan dan sulit meramalkan ketersediaan ternak sebagai barang dagangan (Mulyono dan Sarwono, 2007).

\section{Kapasitas Tampung Ternak Kambing}

Tabel 4. Populasi Ternak Kambing Berdasar Kategori Umur dan Bobot Badan

\begin{tabular}{|c|c|c|c|c|c|c|c|c|}
\hline \multirow[b]{2}{*}{$\begin{array}{l}\text { Bahan } \\
\text { pakan }\end{array}$} & \multirow[b]{2}{*}{$\begin{array}{c}\text { Luas } \\
\text { panen } \\
\text { (ha) }\end{array}$} & \multirow[b]{2}{*}{$\begin{array}{c}\text { Produksi } \\
(\mathrm{kg})\end{array}$} & \multirow{2}{*}{$\begin{array}{c}\text { Total } \\
\text { Produksi } \\
\text { BK } \\
\text { (ton/tahun) }\end{array}$} & \multirow[b]{2}{*}{$\begin{array}{l}\text { Produksi } \\
\text { BK/ha/tahun } \\
\text { (ton) }\end{array}$} & \multicolumn{4}{|c|}{ Kapasitas tampung/tahun } \\
\hline & & & & & UT/ha & Ekor & $\begin{array}{c}\mathrm{UT} / \mathrm{luas} \\
\text { panen }\end{array}$ & Ekor \\
\hline 1 & 42,92 & $1,57 * *$ & 56,42 & 1,52 & 0,83 & 5 & 35,62 & 223 \\
\hline 2 & 31,43 & $1,27 * *$ & 8,3 & 0,46 & 0,24 & 2 & 7,54 & 47 \\
\hline 3 & 0,88 & $0,56^{*}$ & 10,75 & 1,62 & 0,89 & 5 & 1,66 & 9 \\
\hline 4 & 16,08 & $0,86^{*}$ & 327,29 & 3,75 & 2,03 & 12 & 32,64 & 204 \\
\hline 5 & 12,39 & $0,48^{*}$ & 128,25 & 1,61 & 0,88 & 5 & 10,90 & 68 \\
\hline \multicolumn{2}{|l|}{ Jumlah } & & 531,01 & 10,84 & 4,87 & 29 & 88,36 & 551 \\
\hline
\end{tabular}

.Keterangan : 1 = daun gamal, 2 = daun lamtoro, 3 = rumput lapangan, 4 = daun ubi kayu, 5 = daun ubi jalaR, UT= Unit Ternak, $*=$ Produksi/cuplikan $\left(\mathrm{m}^{2}\right), * *=$ Produksi/pohon 
Berdasarkan data pada Tabel 4 produksi masing-masing bahan pakan berdasarkan produksi BK pakan/ha/tahun yaitu 56,42 ton, 8,3 ton, 10,75 ton, 327,29 ton, 128,25 ton dengan total produksi 531,01 ton/tahun. Setelah dilakukan perhitungan dengan kebutuhan BK pada ternak kambing dari asumsi kebutuhan BK 3\% dari bobot hidup (Sianipar dkk, 2006) sehingga berdasarkan ketersediaan BK pakan dari masing-masing jenis bahan dari produksi/luas panen yang diperoleh yaitu 35,62 UT (223 ekor kambing dewasa), 7,54 UT (47 ekor kambing dewasa), 1,66 UT (9 ekor kambing dewasa), 32,64 UT (204 ekor kambing dewasa), 10,90 UT (68 ekor kambing dewasa). Sehingga berdasarkan perhitungan total produksi BK pakan dari seluruh jenis pakan di lokasi penelitian 531,01 ton/tahun dapat memenuhi kebutuhan BK pakan ternak kambing sebanyak 88,36 UT setara dengan 551 ekor ternak kambing dewasa.

Populasi tenak kambing di lokasi penelitian sebanyak 43,84 UT setara dengan 274 ekor kambing dewasa, dengan hasil perhitungan kebutuhan terhadap BK pakan yang ada sebanyak 81 ton/tahun, masih tersisa 450,01 ton BK pakan yang belum termanfaatkan, sehingga masih dapat mengembangkan ternak kambing sebanyak 243,54 UT atau 1.522 ekor kambing dewasa.

\section{Faktor-faktor yang Mempengaruhi Produksi Ternak Kambing}

\section{Hasil Analisis Regresi Berganda}

Output data hasil analisis berganda dalam penelitian ini dapat dilihat pada Tabel 5.

Tabel 5. Hasil pengolahan analisis regresi berganda.

\begin{tabular}{|c|c|c|c|c|c|c|c|c|c|c|c|c|}
\hline \multicolumn{13}{|c|}{ Coefficients $^{\mathrm{a}}$} \\
\hline \multirow[t]{2}{*}{ Model } & \multicolumn{2}{|c|}{$\begin{array}{l}\text { Unstandardiz } \\
\text { ed } \\
\text { Coefficients }\end{array}$} & \multirow{2}{*}{$\begin{array}{c}\text { Stand } \\
\text { ardize } \\
\mathrm{d} \\
\text { Coeff } \\
\text { icient } \\
\mathrm{s} \\
\text { Beta }\end{array}$} & \multirow[t]{2}{*}{$\mathrm{T}$} & \multirow[t]{2}{*}{ Sig. } & \multicolumn{2}{|c|}{$\begin{array}{c}95 \% \\
\text { Confidence } \\
\text { Interval for B }\end{array}$} & \multicolumn{3}{|c|}{ Correlations } & \multicolumn{2}{|c|}{$\begin{array}{c}\text { Collinearity } \\
\text { Statistics }\end{array}$} \\
\hline & B & $\begin{array}{l}\text { Std. } \\
\text { Error }\end{array}$ & & & & $\begin{array}{l}\text { Lower } \\
\text { Bound }\end{array}$ & $\begin{array}{l}\text { Upper } \\
\text { Bound }\end{array}$ & $\begin{array}{l}\text { Zero- } \\
\text { order }\end{array}$ & Partial & Part & $\begin{array}{l}\text { Toler } \\
\text { ance }\end{array}$ & VIF \\
\hline (Constant) & -3.512 & .724 & & -4.852 & $.000 *$ & -4.948 & -2.075 & & & & & \\
\hline $\begin{array}{l}\text { pengalaman } \\
\text { beternak }\end{array}$ & 2.675 & .158 & .828 & 16.891 & $.000 *$ & 2.360 & 2.989 & .873 & .865 & .785 & .900 & 1.112 \\
\hline $\begin{array}{c}\text { jumlah ternak } \\
\text { awal }\end{array}$ & .842 & .336 & .120 & 2.506 & $.014 *$ & .175 & 1.509 & .234 & .248 & .116 & .943 & 1.061 \\
\hline $\begin{array}{l}\text { kepemilikan } \\
\text { induk }\end{array}$ & .835 & .359 & .115 & 2.323 & $.022 *$ & .121 & 1.548 & .382 & .231 & .108 & .889 & 1.125 \\
\hline total $\mathrm{BK}$ pakan & 1.430 & 1.017 & .066 & 1.406 & $.163^{\operatorname{tn}}$ & -.589 & 3.448 & -.027 & .142 & .065 & .970 & 1.031 \\
\hline
\end{tabular}

a. Dependent Variable: jumlah ternak lahir

keterangan: *= signifikan

tn $=$ tidak nyata 
Hasil pengolahan analisis regresi berganda dengan menggunakan software SPSS 16.0 pada Tabel 5 diperoleh persamaan regresi linier berganda sebagi berikut: Ternak lahir/produksi ternak kambing $(\mathrm{Y})=$ $3,512+2,675 \mathrm{X} 1+0,842 \quad \mathrm{X} 2+\quad 0,835$ $\mathrm{X} 3+1,430 \mathrm{X} 4$.

Koefisien regresi untuk variabel bebas X1 (pengalaman beternak) bernilai positif, menunjukkan adanya hubungan yang searah antara pengalaman beternak (X1) dengan jumlah ternak lahir (Y).

Koefisien regresi untuk variabel bebas X3 (kepemilikan induk) bernilai positif, menunjukkan adanya hubungan yang searah antara kepemilikan induk (X3) dengan jumlah ternak lahir (Y).

Koefisien regresi untuk variabel bebas X4 (total BK pakan) bernilai positif menunjukkan adanya hubungan yang searah antara total BK pakan (X4) dengan jumlah ternak lahir (Y).

\section{Pengujian Hipotesis}

Pengujian Hipotesis Secara Simultan (Uji F)

Untuk mengetahui signifikan pengaruh variabel-variabel bebas secara bersama-sama atas suatu variabel terikat digunakan uji F. Hasil pengujian hipotesis secara simultan dengan menggunakan SPSS 16.0.

Tabel 6. Hasil Uji Hipotesis (Uji F)

\begin{tabular}{|c|c|c|c|c|c|c|}
\hline & & & NOVA & & & \\
\hline & & Sum of Squares & Df & Mean Square & $\mathrm{F}$ & Sig. \\
\hline 1 & Regression & 1070.726 & 4 & 267.681 & 91.683 & $.000^{\mathrm{a}}$ \\
\hline & Residual & 280.284 & 96 & 2.920 & & \\
\hline & Total & 1351.010 & 100 & & & \\
\hline
\end{tabular}

a. Predictors: (Constant), total BK pakan, kepemilikan induk, jumlah ternak awal, pengalaman beternak

b. Dependent Variable: jumlah ternak lahir

Berdasarkan output pada Tabel 6 dapat diketahui bahwa nilai F-hitung sebesar 91,683. Adapun nilai F-tabel pada tingkat signifikansi $5 \%$ dan degree of freedom (df) sebesar $\mathrm{k}=4$ dan derajat bebas penyebut (df2) sebesar $\mathrm{n}-\mathrm{k}-1$ $(101-4-1=96)$ adalah sebesar 2,47. Dengan demikian dapat disimpulkan bahwa secara simultan variabel independent (pengalaman beternak, jumlah ternak awal, kepemilikan induk dan total BK pakan) secara bersamasama memiliki pengaruh yang sangat signifikan terhadap variabel dependent (ternak lahir).

\section{Pengujian Hipotesis Secara Parsial}

Berdasarkan kolom signifikan pada masing-masing variabel bebas pada Tabel 5 akan dibahas sebagai berikut :

1. Variabel pengalaman beternak (X1) menunjukkan nilai signifikan sebesar 0,000 , nilai ini lebih kecil dibandingkan dengan nilai $\alpha=0.05(0,000<$ $0,05)$, artinya variabel kriteria pengalaman beternak memiliki pengaruh yang signifikan terhadap jumlah ternak lahir. Dan besarnya nilai koefisien regresi (B) variabel X1 terhadap $\mathrm{Y}$ adalah 2,675. 
2. Variabel jumlah ternak awal (X2) mempunyai nilai signifikan (sig.) sebesar 0,014. Jika dibandingkan dengan $\alpha=0,05$, nilai sig. lebih kecil daripada nilai $\alpha(0,014>0,05)$. Besarnya nilai signifikan untuk variabel $\mathrm{X} 2$ yang ditunjukkan pada Tabel 10 artinya variabel jumlah ternak awal signifikan berpengaruh terhadap variabel jumlah ternak kambing lahir.

3. Variabel jumlah kepemilikan induk (X3) mempunyai nilai signifikan (sig.) sebesar 0,022, artinya variabel jumlah kepemilikan induk berpengaruh positif terhadap variabel jumlah ternak lahir.

4. Variabel total produksi BK pakan (X4) mempunyai nilai signifikan (sig.) sebesar 0,163, artinya variabel total produksi BK pakan tidak berpengaruh terhadap variabel jumlah ternak kambing yang lahir. Berdasarkan data yang diperoleh di lapangan (Tabel 5) bahwa total produksi BK pakan pada masing-masing wilayah kecamatan melebihi kebutuhan populasi ternak kambing yang di wilayah tersebut, sehingga dapat merekomendasikan untuk peningkatan populasi ternak kambing berdasarkan 5. ketersediaan BK pakan.

\section{KESIMPULAN}

Berdasarkan hasil dan pembahasan penelitian maka dapat ditarik kesimpulan bahwa:

1. Berdasarkan karakteristik populasi ternak kambing bahwa jumah pemilikan ternak kambing betina pada setiap struktur umur lebih tinggi dibandingkan ternak jantan sehingga pengembangan populasi akan lebih cepat.

2. Berdasarkan jenis dan penyebarannya, hijauan pakan ternak kambing di Kabupaten Muna Barat dapat memenuhi kebutuhan gizi ternak kambing, karena zat gizi yang terdapat pada masing-masing jenis hijauan yang diberikan akan saling melengkapi dan menjamin ketersediaan gizi pakan.

3. Berdasarkan perhitungan produksi bahan pakan ternak kambing dapat dikatakan bahwa populasi ternak kambing di Kabupaten Muna Barat masih dapat ditingkatkan.

4. Berdasarkan hasil penelitian dapat disimpulkan bahwa secara simultan variabel independen (pengalaman beternak, jumlahternak awal, jumlah induk dan total BK pakan) memiliki pengaruh yang signifikan terhadap produksi ternak kambing di Kabupaten MunaBarat.

\section{DAFTAR PUSTAKA}

Atmojo, S.W. 2007. Menciptakan Taman Kota Berseri. Solo Pos. (28 Mei 2016).

Biro Pusat Statistik. 2015. Kabupaten Muna dalam Angka. Kantor Pusat Statistik Kabupaten Muna.

Biro Pusat Statistik. 2015. Sulawesi Tenggara Dalam Angka. Badan Pusat Statisitik Provinsi Sulawesi Tenggara.

Dinas Pertanian, Peternakan dan Perikanan Kabupaten Muna. 2005. Buku Data Tahunan. 
Dinas Pertanian, Peternakan dan Perikanan Kabupaten Muna. Sulawesi Tenggara.

Ghozali Imam. 2005. Aplikasi Analisis

Multivariat dengan Program

SPSS. Badan Penerbit

Universitas Diponegoro.

Semarang.

Kearl L. C. 1982. Nutrient Requirements of Ruminant in Developing Countries. International Feedstuff Institute. Utah Agricultural Experiment
Station. Utah State University. Logan. Utah.

Mulyono S. dan B. Sarwono. 2008. Penggemukan Kambing Potong. Penebar Swadaya. Jakarta.

Rianse U dan Abdi. 2009. Metodologi Penelitian Sosial dan Ekonomi. $\mathrm{CV}$. Alvabeta. Bandung.

Ruane J dan Andrea Sonnino. 2006. The Role of Biotechnology in Exploring and Protecting Agriculture Genetic Resources. FAO. Roma. 